\title{
Cortical Efferents Lacking Mutant huntingtin Improve Striatal Neuronal Activity and Behavior in a Conditional Mouse Model of Huntington's Disease
}

\author{
[DAna María Estrada-Sánchez, ${ }^{1}$ Courtney L. Burroughs, ${ }^{1}$ Stephen Cavaliere, ${ }^{1}$ Scott J. Barton, ${ }^{1}$ Shirley Chen, ${ }^{1}$ \\ X. William Yang, ${ }^{2}$ and George V. Rebec ${ }^{1}$ \\ ${ }^{1}$ Program in Neuroscience and Department of Psychological and Brain Sciences, Indiana University, Bloomington, Indiana 47405, and ${ }^{2}$ Center for \\ Neurobehavioral Genetics, David Geffen School of Medicine, University of California, Los Angeles, Los Angeles, California 90095
}

\begin{abstract}
Abnormal electrophysiological activity in the striatum, which receives dense innervation from the cerebral cortex, is believed to set the stage for the behavioral phenotype observed in Huntington's disease (HD), a neurodegenerative condition caused by mutation of the huntingtin (mhtt) protein. However, cortical involvement is far from clear. To determine whether abnormal striatal processing can be explained by mhtt alone (cell-autonomous model) or by mhtt in the corticostriatal projection cell-cell interaction model, we used $\mathrm{BACHD} / \mathrm{Emx1-Cre} \mathrm{(BE)} \mathrm{mice,} \mathrm{a} \mathrm{conditional} \mathrm{HD} \mathrm{model} \mathrm{in} \mathrm{which} \mathrm{full-length} \mathrm{mhtt} \mathrm{is} \mathrm{genetically} \mathrm{reduced} \mathrm{in} \mathrm{cortical} \mathrm{output} \mathrm{neurons,}$ including those that project to the striatum. Animals were assessed beginning at 20 weeks of age for at least the next 40 weeks, a range over which presymptomatic BACHD mice become symptomatic. Both open-field and nest-building behavior deteriorated progressively in BACHD mice relative to both BE and wild-type (WT) mice. Neuronal activity patterns in the dorsal striatum, which receives input from the primary motor cortex (M1), followed a similar age progression because BACHD activity changed more rapidly than either BE or WT mice. However, in the M1, BE neuronal activity differed significantly from both WT and BACHD. Although abnormal cortical activity in BE mice likely reflects input from mhtt-expressing afferents, including cortical interneurons, improvements in BE striatal activity and behavior suggest a critical role for mhtt in cortical output neurons in shaping the onset and progression of striatal dysfunction.
\end{abstract}

Key words: BAC-Cre; BACHD mice; Huntington's disease; in vivo electrophysiology; motor cortex; striatum

\section{Introduction}

Huntington's disease (HD) is a dominantly inherited neurological disorder caused by abnormal expansion of a glutamine repeat in the N-terminal domain of the huntingtin protein (htt; The Huntington's Disease Collaborative Research Group, 1993). Although mutant htt (mhtt) is expressed in both neural and nonneural tissues, HD neuropathology is greatest in the cerebral cortex and striatum (Vonsattel and DiFiglia, 1998). Given that the striatum processes information from the entire cortical mantle to shape motor output (Kreitzer and Malenka, 2008), dysfunctional corticostriatal activity is likely to underlie the $\mathrm{HD}$

Received July 10, 2014; revised Jan. 31, 2015; accepted Feb. 8, 2015.

Author contributions: A.M.E.-S. and G.V.R. designed research;A.M.E.-S., C.L.B., S.Ca., S.J.B., and S.Ch. performed research; X.W.Y. contributed unpublished reagents/analytic tools; A.M.E.-S., C.L.B., S.J.B., and G.V.R. analyzed data; A.M.E.-S. and G.V.R. wrote the paper.

This work was supported by the CHDI Foundation. X.W.Y. is supported by National Institutes of Health/National Institute of Neurological Disorders and Stroke Grants R01NS049501 and R01NS074312, the CHDI Foundation, and the Hereditary Disease Foundation. We thank Paul Langley for technical support. We also acknowledge Amanda R. Doyle and Jennifer C. Boatz for their help during data collection.

The authors declare no competing financial interests.

Correspondence should be addressed to Dr. George V. Rebec, Department of Psychological and Brain Sciences, and Program in Neuroscience, 1101 East 10th Street, Bloomington, IN 47405. E-mail: rebec@indiana.edu.

A.M. Estrada-Sánchez's present address: Intellectual and Developmental Disabilities Research Center, Brain Research Institute, David Geffen School of Medicine, University of California, Los Angeles, Los Angeles, CA 90095

DOI:10.1523/JNEUROSCI.2812-14.2015

Copyright $\odot 2015$ the authors $\quad 0270-6474 / 15 / 354440-12 \$ 15.00 / 0$ behavioral phenotype. In fact, both cortical pyramidal neurons (CPNs) and striatal medium spiny neurons (MSNs) show impaired electrophysiological properties along with HD-related motor deficits (Miller et al., 2008; Walker et al., 2008). However, despite ample evidence that impaired striatal processing is a common feature of HD models (Estrada-Sánchez and Rebec, 2013), it is unclear whether striatal dysfunction is caused by the expression of mhtt in MSNs (cell-autonomous toxicity) or whether mhtt in CPNs plays a critical role (cell-cell interaction model; Gu et al., 2005). Because the striatum receives most of its input from the cerebral cortex and the degree of cortical atrophy in motor areas correlates with the extent of the HD motor phenotype (Thu et al., 2010), cortical input may underlie both striatal dysfunction and the development of the HD behavioral phenotype.

Using a conditional mouse model of HD expressing mhttexon 1, Gu et al. (2005) found support for the cell-interaction hypothesis by showing that neuropathology across brain regions occurs only when mhtt is expressed widely. To evaluate the role of mhtt in the corticostriatal system, we recorded presumed CPN and MSN activity in a conditional model in which full-length mhtt is genetically reduced in forebrain glutamate projection neurons, including those that project to the striatum (Wang et al., 2014). These mice are produced by crossing the BACHD mouse model, in which mhtt is expressed throughout the brain (Gray et al., 2008), with a cortex-specific Emxl-Cre/LoxP conditional 
mouse (Iwasato et al., 2000), in which mhtt can be switched off by $\mathrm{Cre}$, a cyclization recombinase. We focused on extracellular spike activity in BACHD/Emx1-Cre (BE), BACHD, and wild-type (WT) controls as they moved freely in an open-field arena. All mice were assessed at regular (typically weekly) intervals for several months to include periods before and after BACHD mice show neurological signs. As another behavioral index, we also monitored nest building, which requires motor coordination and motor sequencing, over the same timeframe.

\section{Materials and Methods}

Animal housing and genotype. All efforts were made to minimize the number of animals used and their suffering.

Animal use was approved by the Institutional Animal Care and Use Committee of Indiana University based on guidelines established by the National Institutes of Health. WT, BE, and BACHD mice were bred from heterozygous pairs ( $\mathrm{FvB} / \mathrm{N}$ background) obtained from the Yang Laboratory at the University of California, Los Angeles. Suppression of mhtt in cortical output neurons of BE mice was confirmed and published recently by the Yang group (Wang et al., 2014). Mice were housed individually and maintained under temperature- and humidity-controlled conditions with a $12 \mathrm{~h}$ light/dark cycle and food and water available $a d$ libitum. Approximately equal numbers of both female and male mice were included in all groups. Both sexes were used because no femalemale differences have been described for the BACHD model (Menalled et al., 2009)

Genotyping was performed on DNA from ear-punch tissue samples in $25 \mu \mathrm{l}$ of cell lysis buffer (50 mu Tris, pH 8.0, 25 mM EDTA, $100 \mathrm{~mm} \mathrm{NaCl}$, $0.5 \%$ IGEPAL CA-630, and $0.5 \%$ Tween 20$)$ and proteinase $\mathrm{K}(10 \mathrm{mg} / \mathrm{ml}$; $60 \mu \mathrm{g} /$ reaction) and incubated at $55^{\circ} \mathrm{C}$ overnight. DNA was diluted with $350 \mu \mathrm{l}$ of filter-sterilized HPLC water, heated to $100^{\circ} \mathrm{C}$ for $10 \mathrm{~min}$, centrifuged for $2 \mathrm{~min}$ at $17,000 \times \mathrm{g}$, and stored at $4^{\circ} \mathrm{C}$. PCR and agarose gel electrophoresis were used to determine genotype. The forward and reverse primers for the CAG repeat region in mhtt were 5' -ATG AAG GCC TTC GAG TCC CTC AAG TCC TTC-3' and 5'-GGC GGC TGA GGA AGC TGA GGA- $3^{\prime}$, respectively. The forward and reverse primers for the Cre marker were 5'-GCG TTC CCC AGA GCC CCG CTA CCT C-3' AND 5'-GGA TCC GCC GCA TAA CCA GTG-3', respectively. Each reaction included $2.0 \mu \mathrm{l}$ of DNA template, $0.4 \mu \mathrm{l}$ of each primer $(20 \mu \mathrm{M}$ stock solution), $7.2 \mu \mathrm{l}$ of filter-sterilized HPLC water, and $10.0 \mu \mathrm{l}$ of $2 \times$ MyTaq Red Mix (Bioline) for $20 \mu \mathrm{l}$ total volume. PCR-cycling conditions for both mhtt and the Cre marker with MyTaq Red Mix were $94^{\circ} \mathrm{C}$ for $180 \mathrm{~s}$, followed by 30 cycles of $94^{\circ} \mathrm{C}$ for $30 \mathrm{~s}, 60^{\circ} \mathrm{C}$ for $20 \mathrm{~s}$, and $72^{\circ} \mathrm{C}$ for $30 \mathrm{~s}$, with a final elongation at $72^{\circ} \mathrm{C}$ for $10 \mathrm{~min}$. Electrophoresis of samples was performed in type I agarose with $0.2 \mu \mathrm{g} / \mathrm{mL}$ ethidium bromide at $5 \mathrm{~V} / \mathrm{cm}$ for $180 \mathrm{~min}$ using a $100 \mathrm{bp}$ ladder as DNA standard. Gels were evaluated with Kodak Image Station 4000R and Kodak Molecular Imaging software (Carestream Molecular Imaging) to confirm genotype.

Electrode implantation surgery. Each of two electrode bundles consisted of four 50- $\mu \mathrm{m}$ Formvar-insulated stainless steel wires (California Fine Wire) and one 50- $\mu \mathrm{m}$ uninsulated stainless steel ground wire. The bundles were friction-fitted to gold pin connectors in a custom nylon hub (6 mm diameter). For most mice $(n=41)$, bundles were implanted bilaterally either in the striatum or the primary motor cortex (M1). However, in some mice $(n=13)$, bundles were implanted unilaterally (in the ipsilateral striatum and M1) to record from both sites simultaneously. The electrode assembly is small, lightweight, and well tolerated by the mice, allowing them to behave freely (Rebec et al., 2006).

Mice were anesthetized with an intraperitoneal injection of a mixture of chloral hydrate and sodium pentobarbital or chloropent $(170 \mathrm{mg} / \mathrm{kg}$ chloral hydrate and $40 \mathrm{mg} / \mathrm{kg}$ sodium pentobarbital; $0.4 \mathrm{ml} / 100 \mathrm{~g}$ body weight) and mounted in a stereotaxic frame. After a midline scalp incision, a hole was drilled through the skull to target the M1 $0.5 \mathrm{~mm}$ anterior and $\pm 1.4 \mathrm{~mm}$ lateral to bregma and $0.5 \mathrm{~mm}$ ventral) or the dorsal striatum $(0.8 \mathrm{~mm}$ anterior and $\pm 2.2 \mathrm{~mm}$ lateral to bregma and 3.2 $\mathrm{mm}$ ventral; Paxinos and Franklin, 2001). Two additional holes were drilled on the contralateral side for stainless anchor screws. After the electrode bundles were lowered, the entire assembly was attached perma- nently to the skull by means of dental acrylic. Mice were allowed at least 1 week of postsurgical recovery in individual cages with food and water available ad libitum.

Electrophysiology. Neuronal activity was recorded during the light phase of the diurnal cycle while the mice freely explored the open field. Recording sessions were conducted once weekly for $30 \mathrm{~min}$ each, beginning when mice were $\sim 20$ weeks of age and continuing for as long as neuronal signals remained viable, typically until mice were 70 weeks of age. The electrode assembly was connected to a lightweight flexible wire harness equipped with field-effect transistors that provided unity-gain current amplification for each of the eight microwires. Neuronal discharges were acquired by a Multichannel Acquisition Processor (MAP) through a preamplifier (Plexon). The MAP system allows for direct computer control of signal amplification, frequency filtering, discrimination, and storage. To detect spiking activity, signals were bandpass filtered $(154 \mathrm{~Hz}$ to $8.8 \mathrm{kHz})$ and digitized at a rate of $40 \mathrm{kHz}$. All spike sorting occurred before the animal was placed in the behavioral chamber for data collection. Sort Client software (Plexon) was used in conjunction with oscilloscope tracking to isolate each unit (matching the analog signal with the digitized template) and to eliminate the need for post hoc offline sorting.

Voltage threshold $>2.5$-fold background noise was established, and a template waveform was created via principal component analysis. Autocorrelation and interspike interval (ISI) analyses were applied to each unit to avoid recording the same unit on multiple channels. In the striatum, we focused on MSNs, which make up $>90 \%$ of the neuronal population. These cells have a characteristic waveform and firing pattern that distinguishes them from other striatal neuronal types (Wilson, 1993). In the M1, neurons were classified by waveform and firing pattern as either fast-spiking units ( $>10$ spikes/s) with narrow afterhyperpolarizations or slow-spiking units $(<10$ spikes/s) with relatively wide afterhyperpolarizations (McCormick et al., 1985). CPNs belong to the latter group and represent the vast majority $(>95 \%)$ of our recordings. All mice participated in multiple recording sessions. Recorded units were treated as independent entities in each recording session because electrode drift and subtle changes in behavioral state cannot guarantee positive detection of the same neuron over multiple sessions (Lewicki, 1998).

Spike train analysis. Electrophysiological data for each recording session were analyzed by means of NeuroExplorer (Nex Technologies). Analysis was performed on single-unit data collected over the entire 30 min recording session. Firing rate was calculated by dividing the spike trains into $1 \mathrm{~s}$ bins (spikes per second). To assess spike-train variability, the coefficient of variation (CV) of ISIs was calculated by dividing the SD of all ISIs in a train by the mean ISI of the train. Bursting activity, which corresponds to periods of high-frequency firing, was calculated by the Poisson surprise method (Legéndy and Salcman, 1985; Miller et al., 2008), which uses a probability-based approach to burst detection that compares successive ISIs in a spike train to a Poisson spike train with the same firing rate. If a set of consecutive ISIs occurs with a sufficiently low probability, the event is considered "surprising" and classified as a burst. In effect, the surprise value indicates how intense or "surprising" are the ISIs of a particular burst compared with other ISIs in the same train and provides an estimate of the statistical significance of each burst in the train (Miller et al., 2008; Estrada-Sánchez et al., 2013). Burst surprise is not sensitive to fluctuations in average firing rate and treats each spike as an independent entity. Moreover, this method is well established for detecting burst activity in the striatum (Aldridge and Gilman, 1991; Stanford and Gerhardt, 2001; Wichmann and Soares, 2006). We used a minimum surprise value of 5 , which estimates that a burst occurs $\sim 150$ times ( $p=0.007)$ more frequently than would be expected in a Poisson spike train with the same mean firing rate (Homayoun et al., 2005). The following bursting properties were analyzed for each recorded neuron: (1) burst rate, (2) percentage of all recorded spikes that occurred in bursts, (3) mean burst surprise, (4) mean burst duration, (5) mean ISI in a burst, (6) mean burst frequency, and (7) mean number of spikes per burst.

To assess correlated activity between two spike trains, crosscorrelation histograms (CCHs) were constructed for each pairwise comparison (Kirkwood, 1979) for each 30 min recording session. All CCHs were based on $0.5 \mathrm{~ms}$ bins and a $0.5 \mathrm{~s}$ time lag from the zero bin. Signif- 
A

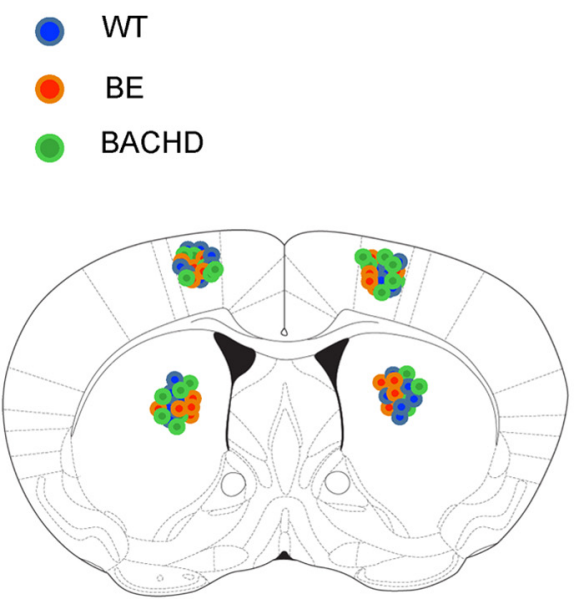

B

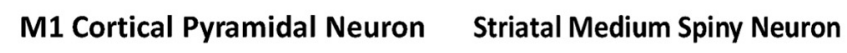

Figure 1. Electrode position and representative waveforms of a presumed MSNs and CPNs. A, Electrode position was verified through histological analysis; the coronal section of the mouse brain shows the position of each electrode bundle in WT (blue), BE (red), and BACHD (green) mice. B, Sample CPN and MSN waveforms collected from a WT mouse. Comparable waveforms were recorded from all groups.

icant peaks, indicating correlated firing in both the raw and smoothed $\mathrm{CCH}$ s, were identified by applying a $99 \%$ confidence interval and assuming the null hypothesis that each spike train is a Poisson process and that firing between neuronal pairs is independent (Abeles, 1982).

Bin sizes for our burst and correlation analyses are determined by an assessment of raw time-stamp data to ensure a dataset appropriate for CPN and MSN activity as in our past work on HD models (Miller et al., 2008; Walker et al., 2008).

Open-field behavior analysis. The open-field arena $(26 \times 18 \mathrm{~cm})$, housed inside a sound-attenuating cubicle, included walls (18 cm high) sloped at a $36^{\circ}$ angle to minimize contact with the wire harness when the mice entered a corner. Mice were behaviorally active during all openfield recording sessions. Three behavioral categories were analyzed as in past work (Hong et al., 2012): (1) exploring (rearing or climbing up the sloped walls), (2) grooming (stereotyped face washing or forelimb or hindlimb scratching), and (3) resting (absence of overt movement). A subset of randomly selected videos of WT $(n=14), \mathrm{BE}(n=19)$, and BACHD $(n=16)$ mice was coded by independent observers blind to genotype.

Nest-building behavior. Nest building was assessed according to the protocol first described by Deacon (2006) and later applied to the huntingtin interacting protein-14 knock-out model (Estrada-Sánchez et al., 2013). Briefly, a new $5 \mathrm{~cm}$ pressed cotton square Nestlet (Ancare) was weighed and placed weekly in the home cage of each mouse. On each of the $3 \mathrm{~d}$ after the placement of the Nestlet, nest quality was assessed on the following scale: 1 , material was mostly unused ( $>90 \%$ intact); 2 , material was partially used (50-90\% intact); 3, material was torn apart and scattered $(<50 \%$ intact $)$ but there was no detectable nest site; 4 , most $(>90 \%)$ of the material was used to make a discernible but flat nest; and 5 , most ( $>90 \%)$ of the material was used to build a complete nest having a central cavity and walls higher than the body height of the mouse. The mass of the remaining unused Nestlet was also weighed on each of the 3 consecutive days after its placement, and the percentage of used material was then calculated. The nest building of WT, BE, and BACHD mice aged 20-60 weeks was monitored.

Histology. Electrode placement was verified in each mouse after the final recording session by deeply anesthetizing the mouse with chloropent and passing a current pulse ( $30 \mu \mathrm{A}$ for $10 \mathrm{~s})$ through each active microwire of each electrode bundle. Mice were perfused and brains were preserved as described previously (Miller et al., 2008). Consecutive series of striatal coronal sections of $40 \mu \mathrm{m}$ were obtained by cryostat and mounted in gelatin-subbed slides. The sections were stained with cresyl violet and examined under a light microscope to confirm electrode bundle location, which was identified as a clear blue spot; only recordings that had electrode placements in the dorsal striatum and M1 were included in the analysis.
Statistical analysis. GraphPad Prism 6 (GraphPad Software) was used for statistical analysis of behavioral and electrophysiological data. The time that mice expend grooming, exploring, or resting was obtained from videotaped sessions of open-field activity, and data were analyzed by two-way ANOVA, followed by Fisher's least significant difference (LSD) multiple comparisons test. The effects of age on open-field behavior and nest building were also analyzed through linear regression. Nonparametric statistics were used to analyze the spike data because of significant deviation from normality and a lack of homogeneous variances in spike-train samples (Walker et al., 2008). Thus, we used the Kruskal-Wallis test, followed by Dunn's multiple comparisons test to compare firing rate, CV ISI, and all bursting parameters. A $\chi^{2}$ test was used to determine differences in the ratio of correlated and noncorrelated neurons. Our electrophysiological data are presented as box-and-whiskers plots; the box extends from the 25 th to the 75 th percentile with the line at the median (50th percentile), and the whiskers represent the minimum and maximum values. Differences were considered significant when $p \leq 0.05$.

\section{Results}

Data were obtained from a total of 54 mice (26 females and 28 males). Between 15 and 20 mice were used for each genotype (WT, $\mathrm{BE}$, and $\mathrm{BACHD}$ ) with approximately equal numbers of mice from both sexes. Similarly, sample sizes of striatal and M1 neurons included comparable numbers from females and males across all three genotypes. Consistent with evidence from BACHD mice (Menalled et al., 2009), no female-male differences emerged, and thus data are reported here without regard to sex. Histological analysis confirmed that microelectrode placements were in the striatum and M1 for all groups, as shown schematically in Figure $1 A$. As depicted for representative recordings in Figure $1 B$, all units displayed waveforms and firing patterns characteristic of MSNs and CPNs, as described previously (Miller et al., 2008; Walker et al., 2008).

\section{Striatal electrophysiology}

In the striatum, we recorded a total of 63 units in WT $(n=11), 73$ units in BE $(n=9)$, and 71 units in BACHD $(n=10)$ mice. In 17 of these mice, our electrode bundles targeted the striatum exclusively, and in 13 mice, striatal recordings were obtained along with M1 data (see also below). Relative to WT neurons, BE and $\mathrm{BACHD}$ units in the striatum showed a significant decrease in firing rate (spikes per second; Fig. $2 A ; p=0.0073$ ). Although the $\mathrm{CV}$ ISI showed no difference between groups, both $\mathrm{BE}$ and 


\section{Striatum}

A

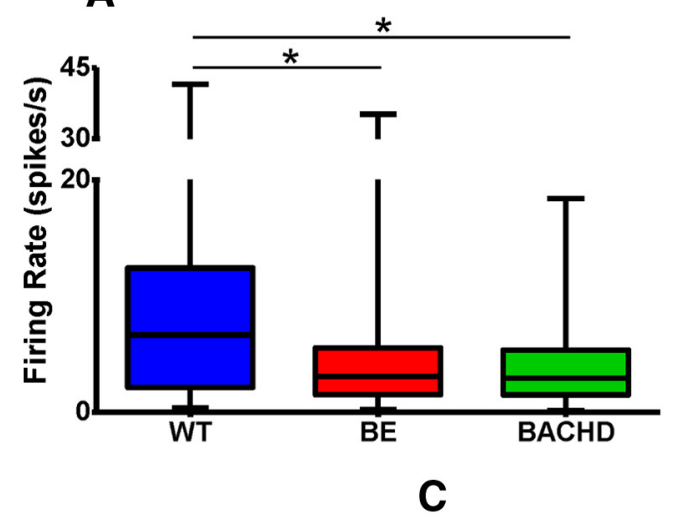

B

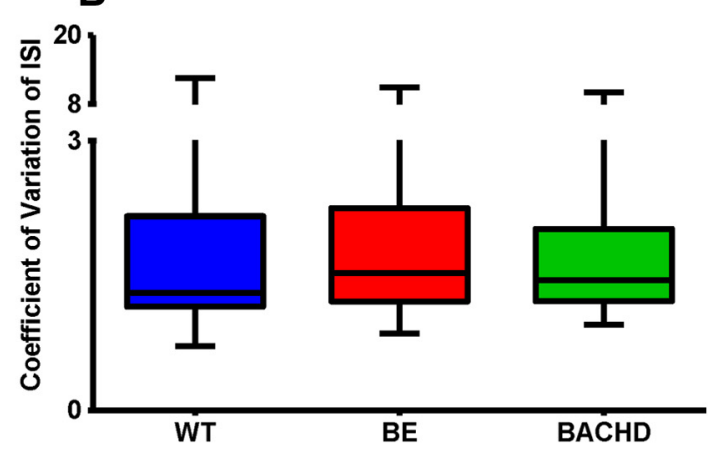

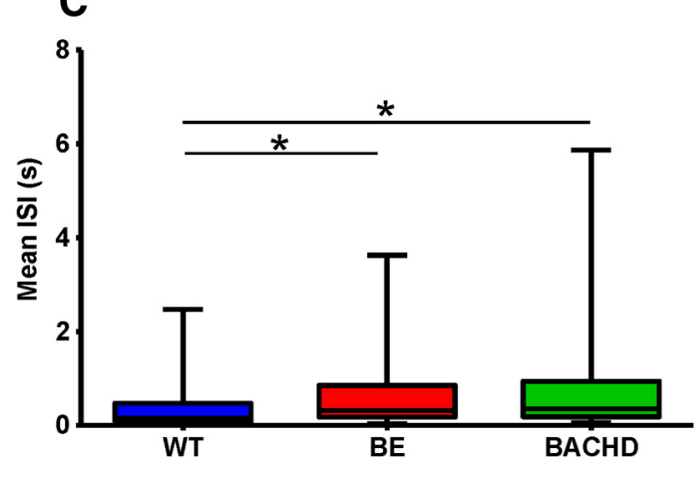

Figure 2. Firing rate and spike train variability in the striatum. Neuronal activity was recorded while mice freely explored an open field for 30 min. Data are illustrated as box-and-whisker plots. The box extends from the 25 th to the 75 th percentile, with the horizontal line in the box indicating the median (50th percentile). The whiskers represent minimum and maximum values. $A$, Firing rate is expressed as the number of spikes per second. $B, C$ V of ISIs. C, Mean ISIs. WT, $n=63 ; B E, n=73$; and BACHD, $n=71$ neurons. Data were analyzed by Kruskal-Wallis test, followed by Dunn's multiple comparisons test. $p=0.0073$ for firing rate and $p=0.0036$ for mean ISI; * indicates relative to WT.

BACHD spike trains showed significant increases in mean ISI (Fig. $2 B, C$, respectively; $p=0.0036$ ).

Consistent with other transgenic models of HD (Miller et al., 2011), BACHD mice showed disrupted burst firing compared with WT. Striatal neurons in BACHD mice showed a significant reduction in bursting activity (bursts per minute; Fig. $3 A ; p=$ 0.036 ) and a corresponding decrease in burst surprise value (Fig. $3 B ; p=0.049$ ), which is an indicator of burst probability within a particular spike train. Although we found no BACHD and WT differences in the percentage of spikes that participate in a burst, the mean burst duration, or the mean interburst interval (Table 1), both $\mathrm{BE}$ and BACHD mice showed a significant reduction in the mean number of spikes that participate in a burst (Fig. $3 C ; p=0.0002$ ). This is consistent with the decrease in firing rate in these same mice, suggesting an HD-related change in the overall pattern of striatal firing involving both spike rate and the structure of spike bursts. However, note that all changes in bursting properties observed in $\mathrm{BE}$ mice are intermediate between WT and BACHD (Fig. 3). Differences in firing rate and bursting among the three groups also can be observed in the spike train raster plots in Figure 4.

\section{Cortical electrophysiology}

In M1 cortex, we recorded neuronal activity from a total of 123 units in WT $(n=14), 149$ units in BE $(n=10)$, and 86 units in BACHD $(n=13)$ mice. In 24 of these mice, data were obtained exclusively from $\mathrm{M} 1$, and, as described above, 13 mice provided both M1 and striatal data. Although cortical neurons in WT and $\mathrm{BE}$ mice showed similar firing rates, the activity of BACHD units was significantly decreased (Fig. 5A; $p<0.0001$ ). Similar changes were observed in mean ISI: although no differences were observed between WT and BE mice, BACHD mice showed a significant increase (Fig. $5 B ; p=0.0003$ ). Interestingly, CPNs in both BE and BACHD mice exhibited increased CV ISI relative to WT. CV ISI was also different between BE and BACHD mice (Fig. $5 C$; $p<0.0001$ ).

Cortical bursting activity in BE mice showed interesting differences compared with WT and BACHD mice. Relative to these two groups, $\mathrm{BE}$ mice had increased burst activity as indicated by burst rate (Fig. $6 A ; p<0.0001$ ) and burst surprise value (Fig. 6B; $p<0.0001)$. Likewise, a significant increase in mean burst duration occurred in BE relative to WT mice (Fig. $6 C$; $p<0.0001$ ), and only BE CPNs significantly increased mean burst duration and significantly decreased mean burst interval (Table $1 ; p<$ $0.05)$. However, both BE and BACHD units increased the percentage of spikes that occur in a burst (Fig. $6 D ; p<0.05$ ). Group differences in cortical firing rate and bursting also can be observed in individual raster plots shown in Figure 7.

\section{Correlated spike activity}

In both truncated and knock-in mouse models of HD, we reported that the temporal relationship of spike activity between simultaneously recorded pairs of neurons is diminished relative to WT controls in both the striatum and cortex (Miller et al., 2008; Walker et al., 2008). We applied this analysis here by constructing $\mathrm{CCH}$ matrices for all pairwise comparisons within each recording session for $\mathrm{WT}, \mathrm{BE}$, and $\mathrm{BACHD}$ mice. The data are summarized in Figure 8. In the striatum (Fig. 8A), the ratio of correlated and noncorrelated neurons shows no difference for all three genotypes $\left(\chi^{2}=3.198, \mathrm{df}=2, p=0.2021\right)$. However, in the 


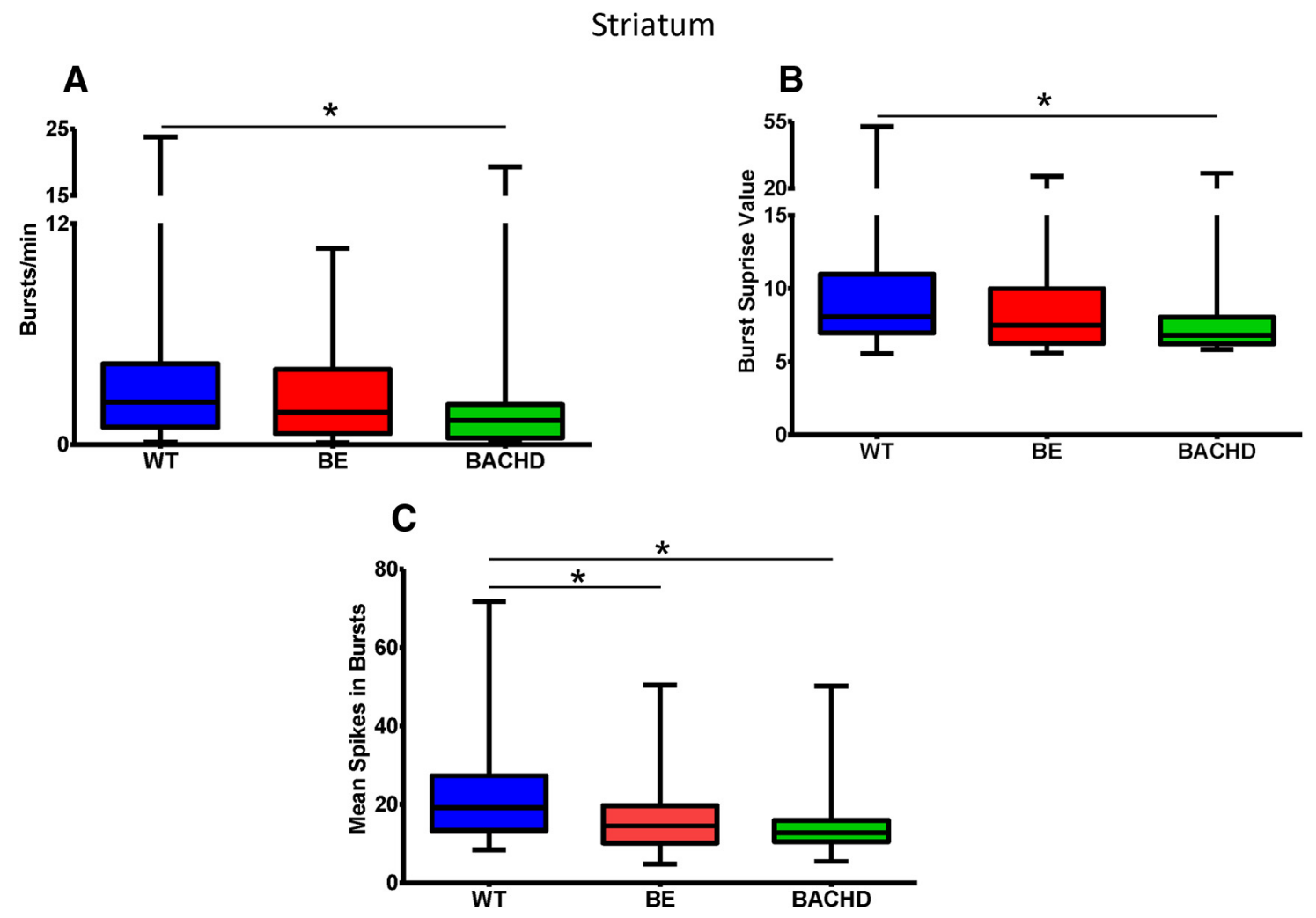

Figure 3. Bursting activity in the striatum as expressed by number of bursts per minute $(\boldsymbol{A})$, burst surprise value $(\boldsymbol{B})$, and mean number of spikes in a burst $(\boldsymbol{C})$. Note that values in $B E$ mice are intermediate between WT and BACHD. $p<0.005$; $^{*}$ indicates relative to WT.

Table 1. Neuronal activity in striatum and $\mathrm{M} 1$ in WT, BE, and BACHD mice

\begin{tabular}{lrrc}
\hline Electrophysiological parameters & \multicolumn{1}{l}{ WT } & \multicolumn{1}{l}{ BE } & \multicolumn{1}{l}{ BACHD } \\
\hline Striatum & & & \\
$\quad$ Percentage spikes in bursts & $24.79 \pm 3.93$ & $25.24 \pm 3.20$ & $17.36 \pm 3.31$ \\
$\quad$ Mean burst duration & $1.02 \pm 0.18$ & $1.23 \pm 0.34$ & $2.13 \pm 0.76$ \\
$\quad$ Mean interburst interval & $39.75 \pm 5.22$ & $55.45 \pm 7.83$ & $68.20 \pm 10.20$ \\
& & & \\
M1 & $12.46 \pm 0.50$ & $18.71 \pm 1.02^{*}$ & $10.72 \pm 0.57^{* *}$ \\
$\quad$ Mean spikes in bursts & $124.00 \pm 17.18$ & $62.53 \pm 10.78^{*}$ & $76.45 \pm 11.27$ \\
$\quad$ Mean interburst interval & &
\end{tabular}

Data are expressed as mean \pm SEM. ${ }^{*} p<0.05$, significantly different from WT mice; ${ }^{* *} p<0.05$, significantly different from BE mice.

M1 (Fig. 8B), the ratio of correlated versus noncorrelated neurons in $\mathrm{WT}, \mathrm{BE}$, and BACHD mice is significantly different $\left(\chi^{2}=\right.$ $19.59, \mathrm{df}=2, p<0.0001)$. Similarly, a significant difference also emerged when we evaluated striatal and M1 firing recorded simultaneously (Fig. $8 C$; $\chi^{2}=28.53$, df $=2, p<0.0001$ ), with BE mice showing the most correlated activity.

\section{Behavioral evaluations: open field}

Mice were behaviorally active for the duration of all recording sessions. Because all sessions were videotaped, a large number of videos were generated. To facilitate data analysis, a subset of randomly selected videos of WT $(n=14), \mathrm{BE}(n=19)$, and BACHD $(n=16)$ mice were coded. Three behavioral categories were analyzed: (1) exploring (rearing or climbing up the sloped walls of the chamber), (2) grooming (stereotyped face washing or forelimb or hindlimb scratching), and (3) resting (absence of overt movement). Figure 9 shows that, across all ages WT, BE, and BACHD mice spend similar amounts of time exploring and resting, although BACHD mice spend significantly more time grooming than WT mice $(p=0.02)$. Note that BE grooming time occupies an intermediate position and is not different from that for WT.

We also analyzed the amount of time that mice spend in these three behavioral categories across age (Fig. 10A-C). Although no significant differences were observed for exploring, a linear regression plot across all ages tested showed a trend toward a decrease in this activity for BACHD mice. Linear regression plots for grooming show that WT mice groom less as they age ( $p=$ $0.05)$, but this effect is not observed in the BE $(p=0.40)$ and BACHD $(p=0.83)$ groups. In fact, BACHD mice spend more time grooming relative to WT across all ages (Fig. 10B). For resting, BE mice $(p=0.02)$ are similar to WT $(p=0.04)$ in spending an increasing amount of time resting as they age. In contrast, BACHD mice show no such relationship $(p=0.20)$.

\section{Behavioral evaluations: nest building}

Nest-building behavior, which is sensitive to motor and cognitive impairment (Szczypka et al., 2001; Fleming et al., 2004), was assessed in mice ( $n=6$ for WT, $n=6$ for BE, $n=7$ for BACHD) from 20 to 60 weeks of age. Performance was determined by the amount of Nestlet used. Figure $11 \mathrm{~A}$ shows that WT mice consistently used almost all the nesting material across all tested ages. In contrast, BACHD mice showed a progressive decrease in this measure (significantly different from 0 slope, $p<0.0001$ ). Note that BE mice show a subtle trend to use less Nestlet, but this effect is not different from 0 slope. Slopes are different between groups $(p<0.0001)$, but no group differences in slope were detected in the degree of completion of the nest (data not shown).

\section{Age-regression analysis of electrophysiological data}

Given that the BACHD HD model develops a progressive HDlike phenotype with age (Gray et al., 2008) and that our results 


\section{Striatum}

WT

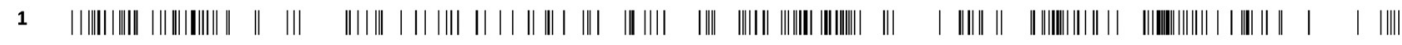

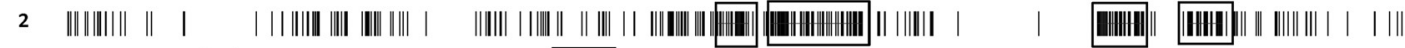

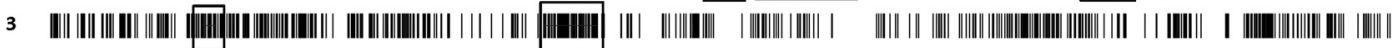

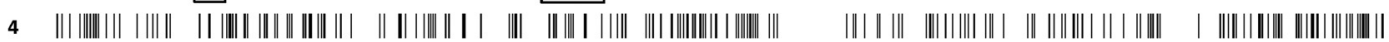

BE

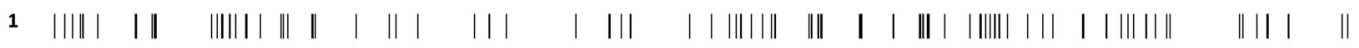

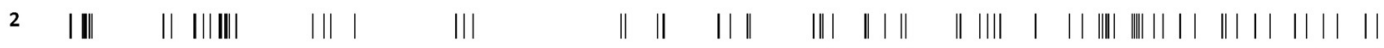

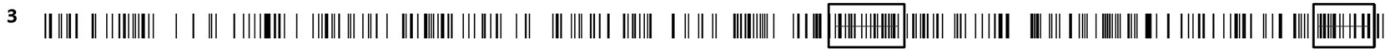

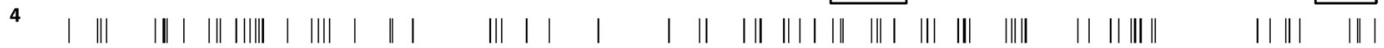

\section{BACHD}

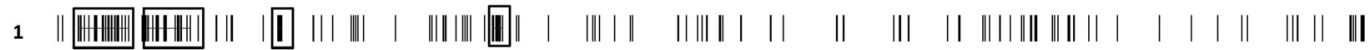

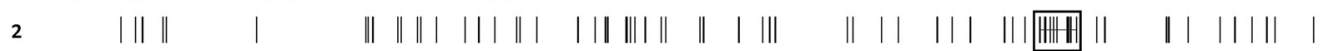

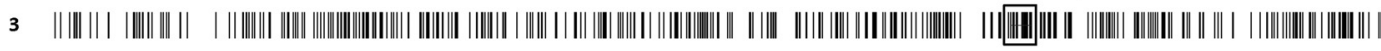

$5 \mathrm{sec}$

Figure 4. Representative spike train raster displays (30 s each) from WT, BE, and BACHD striatal neurons. Samples of three to four neurons were recorded simultaneously from one mouse in each group. Bursts are denoted by boxes.

\section{M1 Cortex}

A

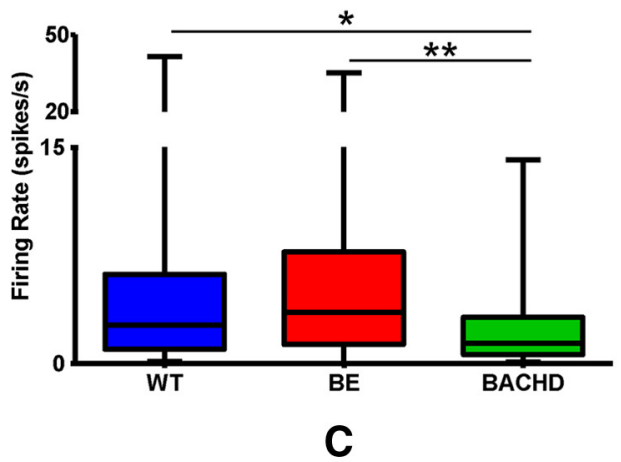

B

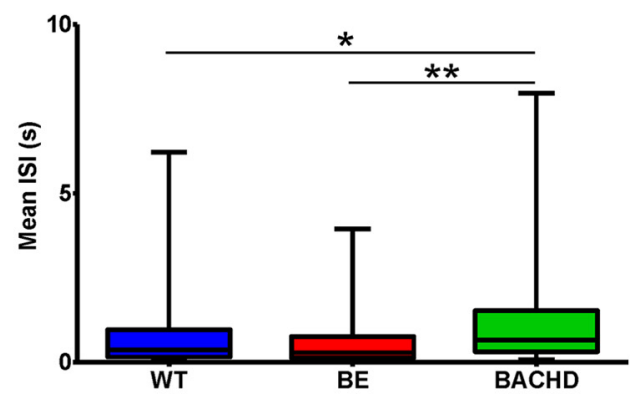

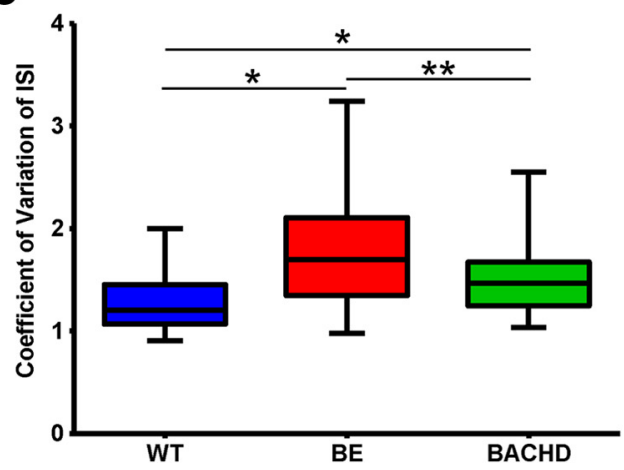

Figure 5. Firing rate and spike train variability in the M1 cortex. $A$, Firing rate. $B$, Mean ISIs. C, CV ISIs. Data are presented as in Figure 2 . WT, $n=123 ; B E, n=149 ;$ and BACHD, $n=86$ neurons. $p<0.0001$ for firing rate, $p=0.0003$ for Mean ISI and $p<0.0001$ for CV ISI; * indicates relative to WT, ${ }^{* *}$ indicates relative to BE.

also show progressive changes in motor behavior (Figs. 10, 11), we applied our age-regression analysis to our neuronal recordings and examined parallels with our behavioral data. Interestingly, as shown in Figure 10D, when we evaluated M1 firing rate across age, all three groups showed regression plots that closely paralleled time resting such that WT and BE firing were significantly different from 0 slope $(p=0.0005$ and $p=0.0003$, respectively) but not BACHD $(p=0.20)$. Likewise, we observed that progressive impairment in the amount of Nestlet used in BACHD mice (Fig. 11A) parallels a progressive change 


\section{M1 Cortex}
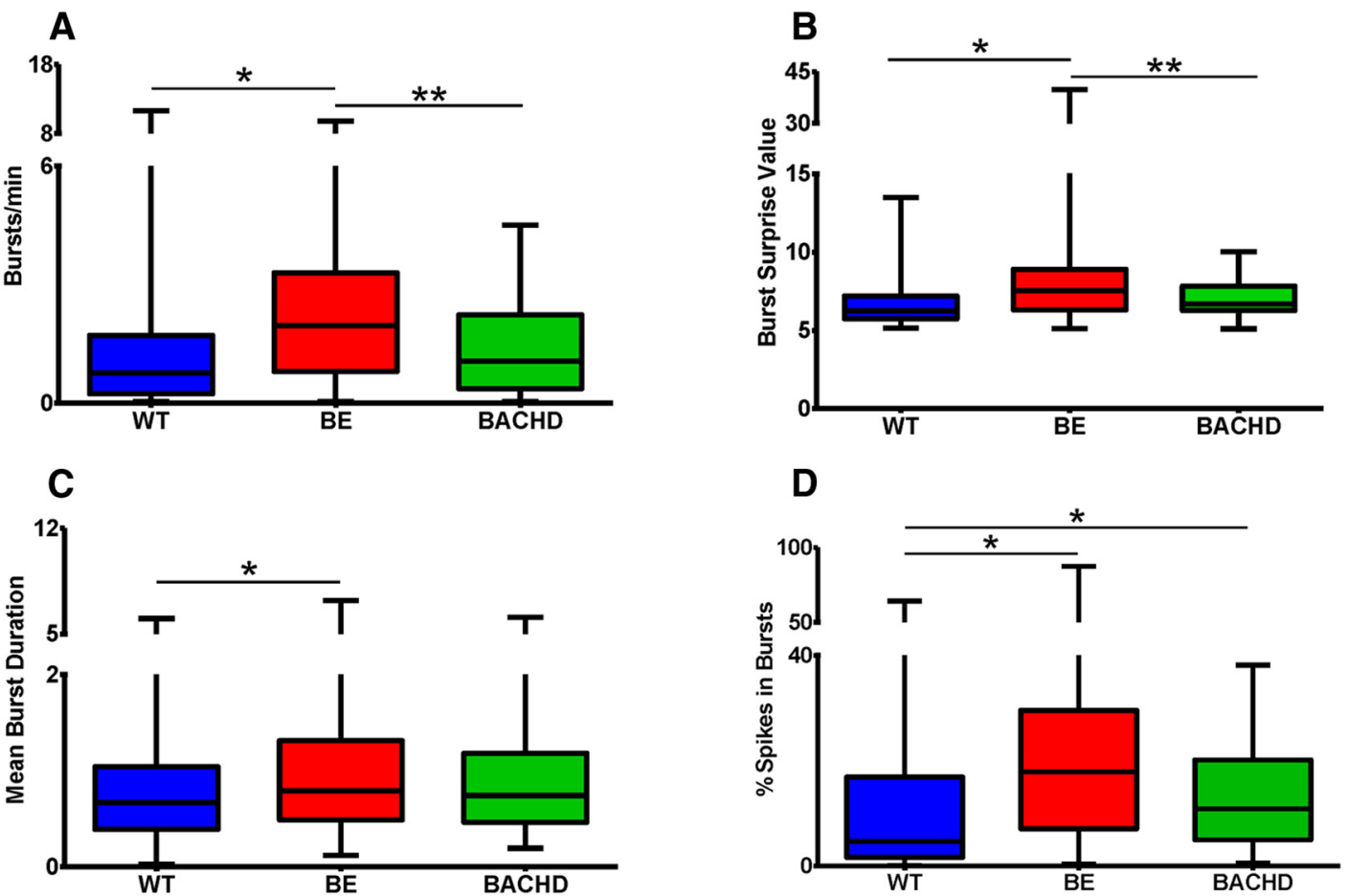

Figure 6. Bursting activity in $M 1$ cortical neurons as expressed by number of bursts per minute $(\boldsymbol{A})$, burst surprise value $(\boldsymbol{B})$, mean burst duration $(\boldsymbol{C})$, and percentage of spikes in a burst (D). $\boldsymbol{A}-\boldsymbol{C}$, $p<0.0001 ; \boldsymbol{D}, p<0.005 ;{ }^{*}$ indicates relative to $\mathrm{WT},{ }^{* *}$ indicates relative to $\mathrm{BE}$.

\section{M1 Cortex}

\section{WT}

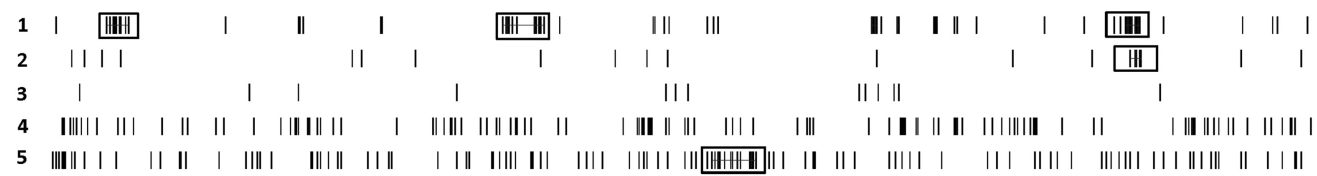

\section{BE}

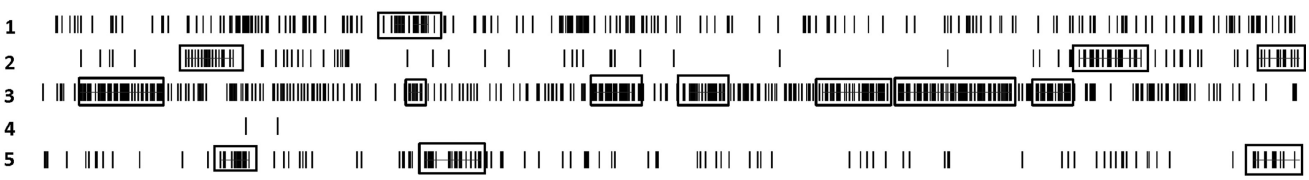

\section{BACHD}

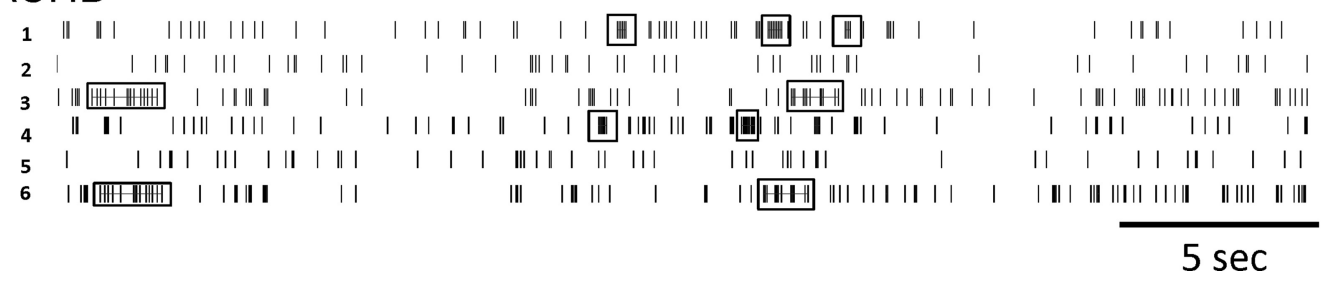

Figure 7. Representative spike train raster displays ( $30 \mathrm{~s}$ ) from WT, BE, and BACHD M1 cortical neurons. Samples of five to six neurons were recorded simultaneously from one mouse in each group. Bursts are denoted by boxes.

in multiple burst properties in BACHD striatum, including burst surprise value (Fig. 11B), mean number of spikes in a burst (Fig. 11C), and mean burst duration (Fig. 11D). In each case, there is an age-related decline in BACHD mice but not WT or BE mice.

\section{Discussion}

The neuropathology of HD is characterized by the loss of MSNs, followed by CPNs (de la Monte et al., 1998). Because the cerebral cortex sends massive and widespread projections to the striatum, it is likely that cortical neurons contribute to the dysregulation of 
A

Striatum

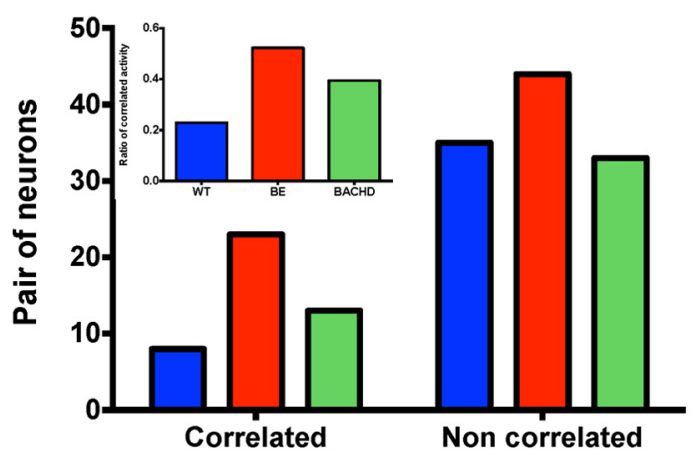

B

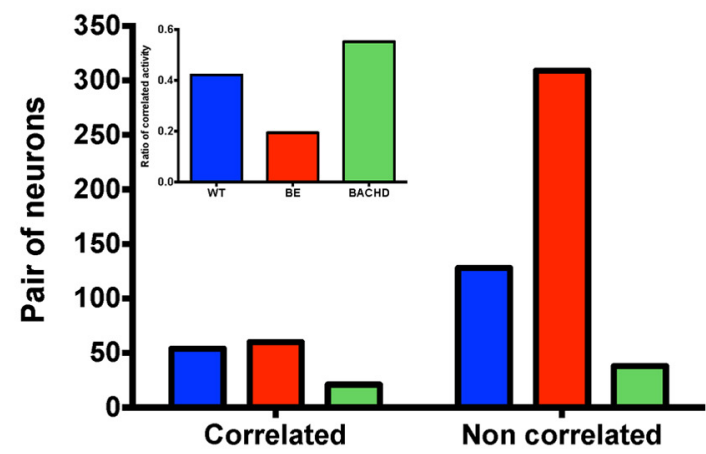

C

M1 vs Striatum

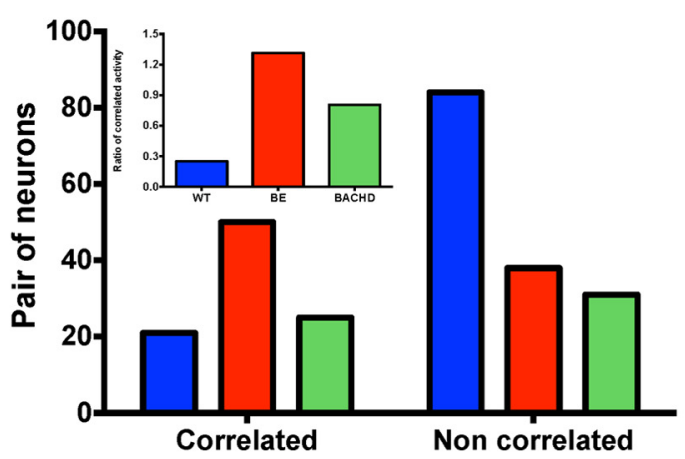

Figure 8. Instances of correlated neuronal activity in WT, BE, and BACHD mice. Total number of correlated and noncorrelated neurons in the striatum $(A), M 1$ cortex (B), and striatum versus $M 1$ cortex ( $(C)$. Insets show the ratio of correlated to noncorrelated neurons per genotype. Data were analyzed by $\chi^{2}$ test: for striatum, $\chi^{2}=3.198, p=0.2021\left(n=43\right.$ forWT, $n=67$ for BE, and $n=46$ pairs of neurons for BACHD); for M1, $\chi^{2}=19.59$, $p<0.0001$ ( $n=182$ for WT, $n=369$ for BE, and $n=59$ pairs of neurons for BACHD); and for striatum versus M1, $\chi^{2}=28.53, p<0.0001$ ( $n=105$ for WT, $n=88$ for BE, and $n=56$ pairs of neurons for BACHD).

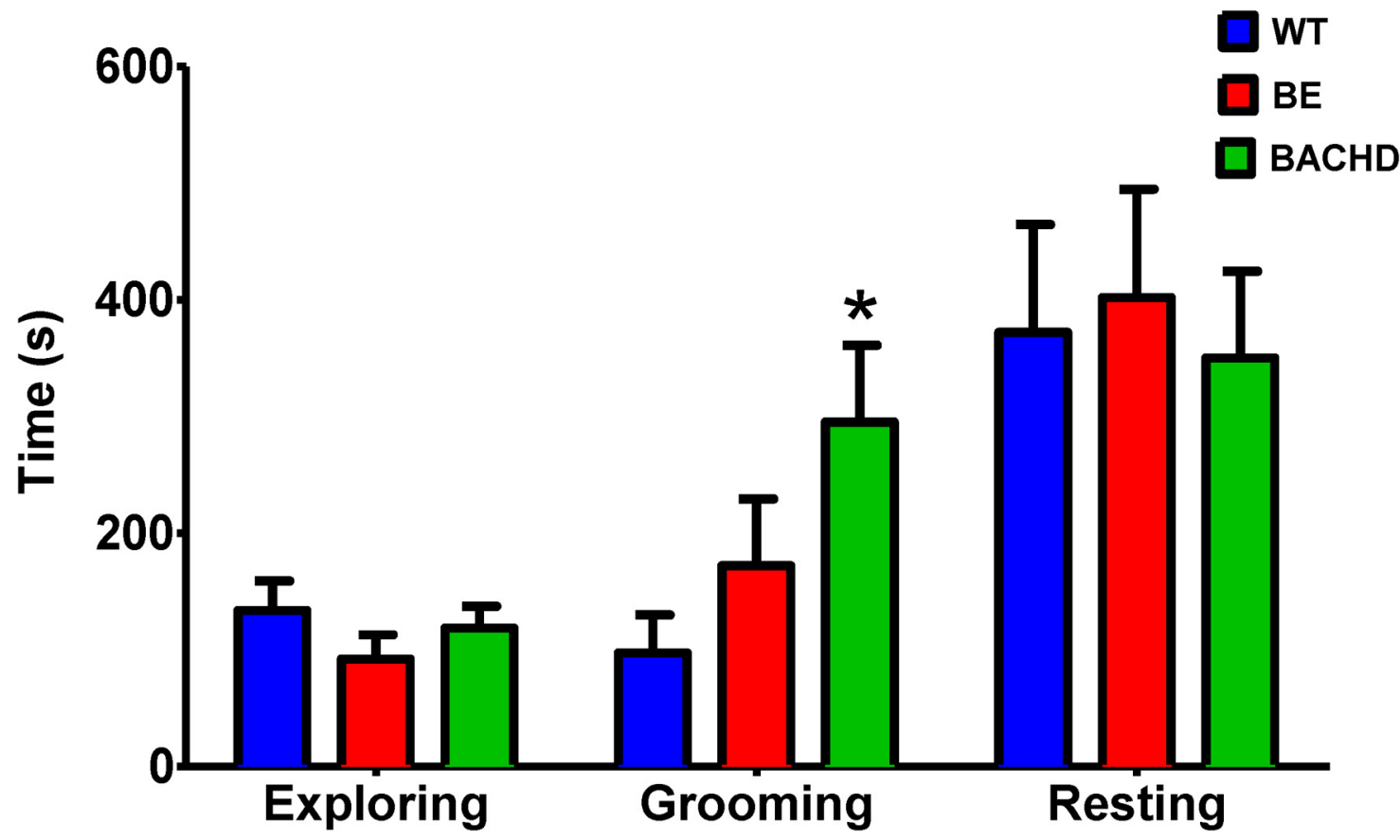

Figure 9. Mean \pm SEM time that WT $(n=14), \mathrm{BE}(n=19)$, and BACHD $(n=16)$ mice spent exploring, grooming, and resting in the open field. Data were analyzed by two-way ANOVA and Fisher's LSD multiple comparisons test. ${ }^{*} p=0.019$, significantly different from WT.

striatal activity described for HD (for review, see Estrada-Sánchez and Rebec, 2012). Here, we demonstrate that striatal firing patterns, particularly bursting, in $\mathrm{BE}$ mice with genetic reduction of full-length mhtt no longer resemble those of BACHD mice but occupy an intermediate position between BACHD and WT mice. $\mathrm{BE}$ motor deficits also are reduced relative to BACHD. To our knowledge, this is the first in vivo evidence indicating that mhtt in cortical output neurons plays a critical role in shaping the aber- 

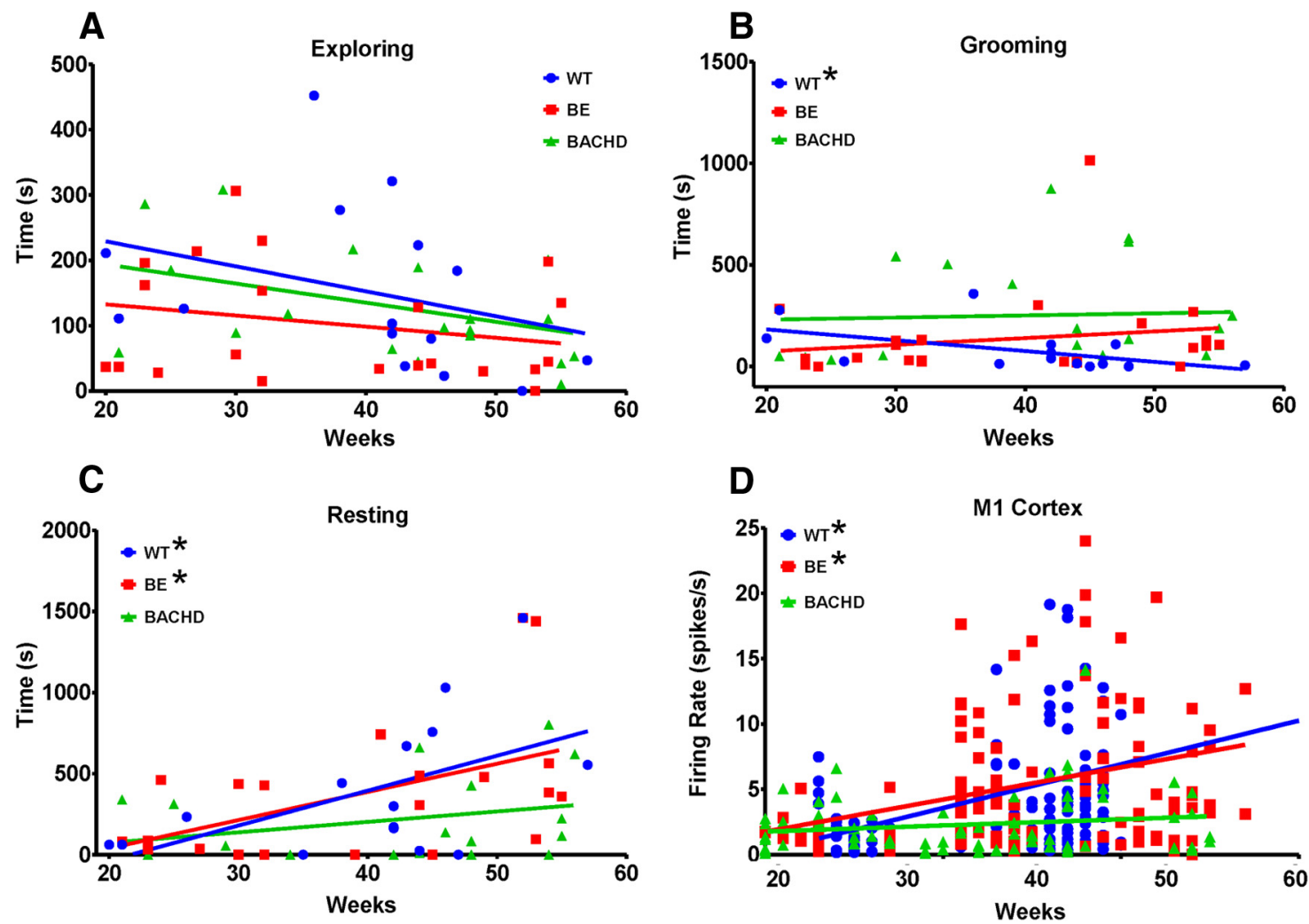

Figure 10. Linear regression plots of time spent exploring $(\boldsymbol{A})$, grooming $(\boldsymbol{B})$, and resting $(\boldsymbol{C})$ and for $M 1$ firing rate $(\boldsymbol{D})$ across all ages studied. For $\boldsymbol{A}-\boldsymbol{C}$, each individual symbol represents the amount of time exploring, grooming, or resting by an individual mouse at a specific age, whereas for $\boldsymbol{D}$, each symbol represents the firing rate for each neuron recorded. ${ }^{*}$ significantly different from 0 slope: for grooming, $p=0.05$ for WT; for resting, $p=0.04$ for WT and $p=0.02$ for BE; and for firing rate in M1 neurons, $p=0.0005$ for WT and $p=0.0003$ for $\mathrm{BE}$. $r^{2}$ values: for exploring $(A)$, $W T=0.1027, B E=0.05361$, and $B A C H D=0.1676$; for grooming $(B), W T=0.2567, B E=0.03305$, and $B A C H D=0.002330$; for resting $(C), W T=0.2811, B E=0.2474$, and $B A C H D=0.08954$; for $\mathrm{M} 1$ firing rate $(\boldsymbol{D}), \mathrm{WT}=0.1050, \mathrm{BE}=0.09828$, and $\mathrm{BACHD}=0.02291$.

rant striatal electrophysiology and behavioral phenotype characteristic of HD models.

Interestingly, although the $\mathrm{BE}$ striatum receives cortical input devoid of mhtt, not all aspects of MSN activity are the same as WT. Firing rate and mean ISI, for example, show no improvement relative to $\mathrm{BACHD}$. These persistent effects may reflect the continuing influence of mhtt in MSNs and thus a cellautonomous contribution. Two well known cell-autonomous effects-mhtt aggregation and transcription abnormalities ( $\mathrm{Gu}$ et al., 2005; Thomas et al., 2011) —-may occur in BE mice and prevent a complete elimination of the BACHD neurobehavioral phenotype. However, despite the persistence of the BACHD striatal firing rate in $\mathrm{BE}$ mice, we consistently observed improvements in striatal burst properties in BE mice that approached WT values. Thus, cortical inputs impose a bursting pattern of striatal activity independently of MSN background firing rate. Although this effect is disrupted in BACHD mice, it is partially rescued by Cre-mediated genetic reduction of full-length mhtt expression in cortical output neurons. Similar results were observed in vitro by Wang et al. (2014), who reported that MSN spontaneous activity in BACHD mice display a significant reduction of EPSCs and an increase in IPSCs, which are ameliorated in BE mice. Therefore, it appears that striatal neuropathology in HD includes both cellautonomous and cell-cell interaction mechanisms ( $\mathrm{Gu}$ et al., 2005; Wang et al., 2014).

In the M1 cortex, the electrophysiological properties of BE mice differ significantly from both BACHD and WT. For example, Figures 5 and 6 show BE differences in CV ISI, burst rate, and burst surprise value. Although mhtt is suppressed in cortical out- put cells, these same neurons continue to receive input from interneurons and cortical afferents that still express mhtt. Such input likely contributes to the abnormal activity of CPNs in $\mathrm{BE}$ mice. By itself, the suppression of mhtt in cortical output neurons is not sufficient to rescue the electrophysiological activity of these cells. Again, cell-cell interactions are critical.

Surprisingly, despite abnormalities in cortical firing, activity in $\mathrm{BE}$ striatum shows improvement toward WT and away from BACHD, suggesting that genetic reduction of full-length mhtt alters how cortical neurons communicate with their striatal targets. Extreme changes in BE cortical activity, beyond the changes that occur in BACHD mice, may be required to rescue at least some aspects of striatal activity. Because burst activity is thought to strengthen neuronal processing (Lisman, 1997; Izhikevich et al. 2003), the abnormal bursting changes observed in BE mice may represent a compensatory response to dysfunctional inputs that express mhtt. Although the effects of HD on the activity of $\mathrm{CPN}$ afferents are essentially unknown, reduced input from GABAergic interneurons has been described for HD mice ( $\mathrm{Gu}$ et al., 2005; Cummings et al., 2009). In the BACHD model, parvalbumin-containing interneurons show alterations in the decay kinetics of spontaneously occurring IPSCs and EPSCs (Spampanato et al., 2008). Similarly, a study of postmortem tissue samples indicates that region-specific degeneration of cortical interneurons contributes to HD symptoms (Kim et al., 2014). Dysfunctional thalamocortical projections also may contribute to abnormal BE CPN activity given that HD-related changes in thalamic neurons have been reported (Deng et al., 2013). Collectively, these results suggest that cell-cell interactions involving 
A
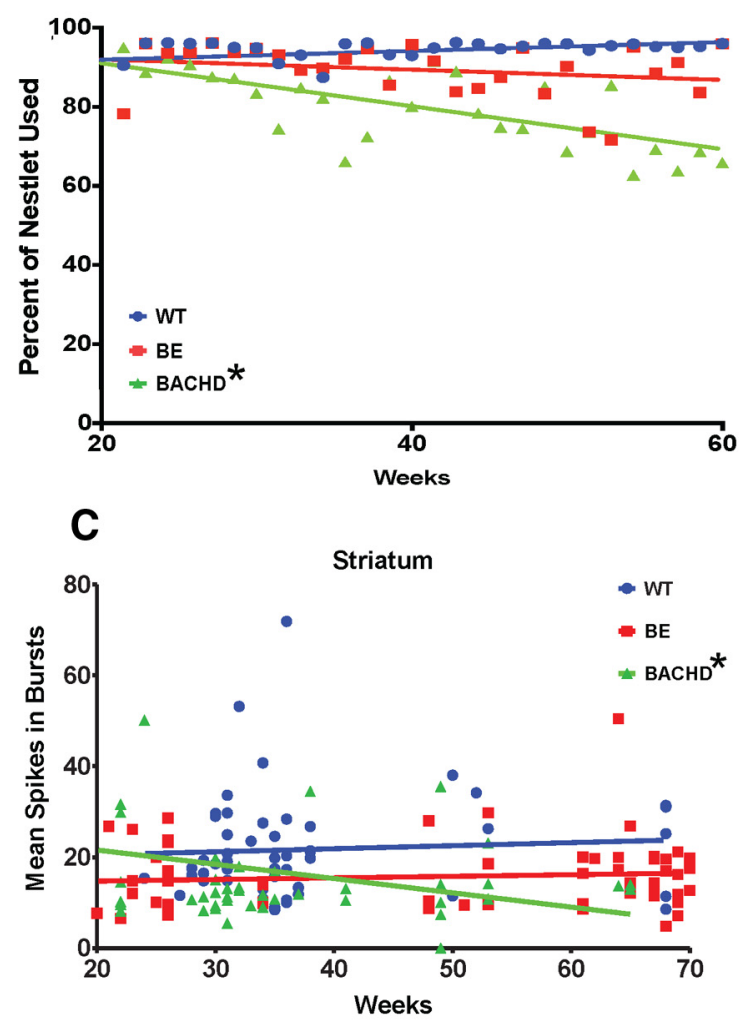

B
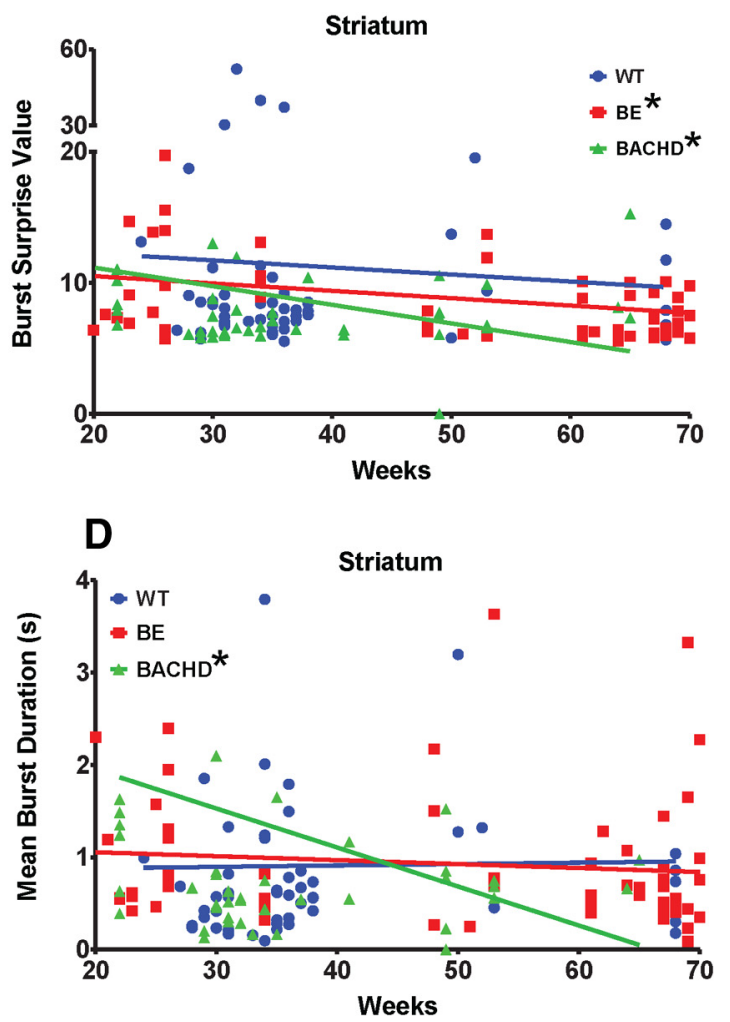

Figure 11. Impaired nest-building performance in BACHD mice. Nest-building activity was evaluated from 20 to 60 weeks of age. $A$, Percentage of Nestlet used; $n=6$ for WT, $n=6$ for $B E$, and $n=7$ for $B A C H D . r^{2}$ values: $\mathrm{WT}=0.03557, \mathrm{BE}=0.01926$, and $\mathrm{BACHD}=0.1406 . \boldsymbol{B}-\boldsymbol{D}$, Changes in bursting properties in striatal neurons that parallel the percentage of Nestlet used: $\boldsymbol{B}$, mean burst surprise $\left(r^{2}\right.$ values: $\mathrm{WT}=0.004470, \mathrm{BE}=0.07298$, and $\left.\mathrm{BACHD}=0.08890\right) ; \boldsymbol{C}$, spikes in burst $\left(r^{2}\right.$ values: $\mathrm{WT}=0.004399, \mathrm{BE}=0.002802$, and $\left.\mathrm{BACHD}=0.1130\right)$; and $\boldsymbol{D}$, burst duration $\left(r^{2}\right.$ values: $\mathrm{WT}=0.0009487, \mathrm{BE}=0.003512$, and $\mathrm{BACHD}=0.01354)$. Data were analyzed by linear regression. * indicates significantly different from 0 slope: for mean burst surprise, $p=0.03$ for $\mathrm{BE}$ and $p=$ 0.02 for $B A C H D$; for spikes in burst, $p=0.02$ for BACHD; and for burst duration, $p=0.03$ for BACHD. Average age of mice used for $\boldsymbol{B}-\boldsymbol{D}$ : WT, $37.8 \pm 1.5$ weeks, $B E, 49.66 \pm 2.4$ weeks, and BACHD, $35.04 \pm 1.8$ weeks.

cortical microcircuits and cortical afferents are important for shaping aberrant activity in the HD cortex.

Cortical astrocytes, which also express mhtt, may contribute to abnormal BE CPN activity by failing to regulate extracellular glutamate and other key aspects of synaptic transmission. Altered glutamate release in HD has been described both in vitro and in vivo (Nicniocaill et al., 2001; Li et al., 2003). Although a similar concentration of glutamate has been described in the striatum of WT and HD models (Traficante et al., 2007), impaired glutamate signaling might occur in $\mathrm{HD}$ as a consequence of decreased glutamate uptake. Consistent evidence from HD postmortem brain samples and HD transgenic models have shown a decreased functioning of glutamate transporter 1, also known as GLT1, which is the astrocytic protein responsible for the bulk of glutamate uptake (Liévens et al., 2001; Behrens et al., 2002; Hassel et al., 2008). Impaired removal of glutamate at corticostriatal synapses might compromise the dynamic of synaptic transmission, leading to aberrant neuronal processing (Beurrier et al., 2009), a hallmark of HD transgenic models (Miller et al., 2008; Estrada-Sánchez and Rebec 2012, 2013). Moreover, deficient glutamate uptake also might promote glutamate spillover, which in turn will activate extrasynaptic NMDA receptors and trigger excitotoxic neuronal damage (Milnerwood et al., 2010). Consistent with this view, increased glutamate-induced neuronal damage correlates with decreased levels of glutamate transporters in the striatum of the R6/2 transgenic model (Estrada-Sánchez et al., 2009). Besides glutamate uptake failure, growing evidence indicates that astro- cytes may contribute to HD neuropathology by other mechanisms, such as impaired ascorbate release and altered potassium homeostasis (Miller et al., 2012; Lee et al., 2013; Tong et al., 2014).

The partial rescue of striatal activity in BE mice may involve protein and structural changes. For example, these mice show improvement in striatal levels of synaptophysin and postsynaptic density-95 (Wang et al., 2014), whereas the impaired release of BDNF, which has been reported consistently for HD (Zuccato et al., 2001), may be at least partially reversed in BE striatum. Morphological changes at the level of the corticostriatal synapse also are possible (Unschuld et al., 2012).

Functionally, a change in the ratio of correlated to noncorrelated pairs of recorded neurons may play a role in the behavioral improvement of BE mice. Although the ratio is similar for all three genotypes in the striatum and M1, an increased number of M1 and striatal correlated neuron pairs occurs in $\mathrm{BE}$ mice. The significance of this corticostriatal interaction is unclear, but it likely represents a key mechanism in the improved behavioral phenotype of BE mice.

In our assessment of open-field behavior, we found no group differences in the amount of resting and exploring behavior, but the time $\mathrm{BE}$ mice spent grooming was intermediate between the values observed in the WT and BACHD groups. Repetitive grooming has elements of an invariant or stereotyped response, which has been observed consistently in both HD patients and transgenic mice (Cyr et al., 2006; Chen et al., 2013). Our BACHD result support this evidence in that $\mathrm{BE}$ grooming is not different from WT. Our electrophysiological data also show age-related 
changes that parallel behavior. For example, M1 firing and time spent resting are closely parallel in all three groups, with WT and $\mathrm{BE}$ mice showing a progressive increase with age and the lack of a such a change in BACHD mice (Fig. 10C,D). Similar age-related parallels were observed between nest building and changes in MSN bursting. For nest building, mice rely on the coordinated activity of forelimbs and orofacial muscles (Fleming et al., 2004; Estrada-Sánchez et al., 2013). BACHD mice leave increasing amounts of nest material unused as they age, a sign of impaired motor coordination (Spampanato et al., 2008; Wang et al. 2014). In contrast, $\mathrm{BE}$ mice perform close to the WT level, and the improved nest building parallels the rescue in striatal bursting properties. This is a very interesting relationship because nest building is associated with thermoregulation and shelter, which depend on striatal function (Szczypka et al., 2001). In fact, we found that the progressive BACHD impairment in nest building parallels the disruption of striatal bursting (Fig. 11). Both are restored in the BE model, suggesting that $\mathrm{M} 1$ projections importantly contribute to the progressive deterioration of motor behavior and neuronal activity in BACHD mice. Although improved nest building in $\mathrm{BE}$ mice may be attributable mainly to the reduction of mhtt in CPNs, other structures, such as the hippocampus, which also show a decreased expression of mhtt (Wang et al., 2014), are possible contributors. In fact, there is evidence that impaired hippocampal activity leads to decreased nest building in the Alzheimer's disease transgenic model (OrtaSalazar et al., 2013).

Together, our results indicate that expression of mhtt in cortical outputs is a key contributor to impaired striatal processing in HD. The partial but significant improvement in both striatal neuronal activity and behavior in BE mice implicate the cortex as a potential target for HD treatment. However, the aberrant activity of cortical neurons in $\mathrm{BE}$ mice also suggests that additional work is required to identify the influence of mhtt on cortical processing.

\section{References}

Abeles M (1982) Quantification, smoothing, and confidence limits for single-units' histograms. J Neurosci Methods 5:317-325. CrossRef Medline

Aldridge JW, Gilman S (1991) The temporal structure of spike trains in the primate basal ganglia: afferent regulation of bursting demonstrated with precentral cerebral cortical ablation. Brain Res 543:123-138. CrossRef Medline

Behrens PF, Franz P, Woodman B, Lindenberg KS, Landwehrmeyer GB (2002) Impaired glutamate transport and glutamate-glutamine cycling: downstream effects of the Huntington mutation. Brain 125:1908-1922. CrossRef Medline

Beurrier C, Bonvento G, Kerkerian-Le Goff L, Gubellini P (2009) Role of glutamate transporters in corticostriatal synaptic transmission. Neuroscience 158:1608-1615. CrossRef Medline

Chen JY, Wang EA, Cepeda C, Levine MS (2013) Dopamine imbalance in Huntington's disease: a mechanism for the lack of behavioral flexibility. Front Neurosci 7:114. CrossRef Medline

Cummings DM, André VM, Uzgil BO, Gee SM, Fisher YE, Cepeda C, Levine MS (2009) Alterations in cortical excitation and inhibition in genetic mouse models of Huntington's disease. J Neurosci 29:10371-10386. CrossRef Medline

Cyr M, Sotnikova TD, Gainetdinov RR, Caron MG (2006) Dopamine enhances motor and neuropathological consequences of polyglutamine expanded huntingtin. FASEB J 20:2541-2543. CrossRef Medline

Deacon RM (2006) Assessing nest building in mice. Nat Protoc 1:11171119. CrossRef Medline

de la Monte SM, Vonsattel JP, Richardson EP Jr (1988) Morphometric demonstration of atrophic changes in the cerebral cortex, white matter, and neostriatum in Huntington's disease. J Neuropathol Exp Neurol 47: 516-525. CrossRef Medline
Deng YP, Wong T, Bricker-Anthony C, Deng B, Reiner A (2013) Loss of corticostriatal and thalamostriatal synaptic terminals precedes striatal projection neuron pathology in heterozygous Q140 Huntington's disease mice. Neurobiol Dis 60:89-107. CrossRef Medline

Estrada-Sánchez AM, Rebec GV (2012) Corticostriatal dysfunction and glutamate transporter 1 (GLT1) in Huntington's disease: interactions between neurons and astrocytes. Basal Ganglia 2:57-66. CrossRef Medline

Estrada-Sánchez AM, Rebec GV (2013) Role of cerebral cortex in the neuropathology of Huntington's disease. Front Neural Circuits 7:19. CrossRef Medline

Estrada-Sánchez AM, Montiel T, Segovia J, Massieu L (2009) Glutamate toxicity in the striatum of the R6/2 Huntington's disease transgenic mice is age dependent and correlates with decreased levels of glutamate transporters. Neurobiol Dis 34:78-86. CrossRef Medline

Estrada-Sánchez AM, Barton SJ, Burroughs CL, Doyle AR, Rebec GV (2013) Dysregulated striatal neuronal processing and impaired motor behavior in mice lacking huntingtin interacting protein 14 (HIP14). PLoS One 8:e84537. CrossRef Medline

Fleming SM, Salcedo J, Fernagut PO, Rockenstein E, Masliah E, Levine MS, Chesselet MF (2004) Early and progressive sensorimotor anomalies in mice overexpressing wild-type human $\alpha$-synuclein. J Neurosci 24:94349440. CrossRef Medline

Gray M, Shirasaki DI, Cepeda C, André VM, Wilburn B, Lu XH, Tao J, Yamazaki I, Li SH, Sun YE, Li XJ, Levine MS, Yang XW (2008) Fulllength human mutant huntingtin with a stable polyglutamine repeat can elicit progressive and selective neuropathogenesis in BACHD mice. J Neurosci 28:6182-6195. CrossRef Medline

Gu X, Li C, Wei W, Lo V, Gong S, Li SH, Iwasato T, Itohara S, Li XJ, Mody I, Heintz N, Yang XW (2005) Pathological cell-cell interactions elicited by a neuropathogenic form of mutant Huntingtin contribute to cortical pathogenesis in HD mice. Neuron 46:433-444. CrossRef Medline

Hassel B, Tessler S, Faull RL, Emson PC (2008) Glutamate uptake is reduced in prefrontal cortex in Huntington's disease. Neurochem Res 33:232-237. CrossRef Medline

Homayoun H, Jackson ME, Moghaddam B (2005) Activation of metabotropic glutamate $2 / 3$ receptors reverses the effects of NMDA receptor hypofunction on prefrontal cortex unit activity in awake rats. J Neurophysiol 93:1989-2001. Medline

Hong SL, Cossyleon D, Hussain WA, Walker LJ, Barton SJ, Rebec GV (2012) Dysfunctional behavioral modulation of corticostriatal communication in the R6/2 mouse model of Huntington's disease. PLoS One 7:e47026. CrossRef Medline

Iwasato T, Datwani A, Wolf AM, Nishiyama H, Taguchi Y, Tonegawa S, Knöpfel T, Erzurumlu RS, Itohara S (2000) Cortex-restricted disruption of NMDAR1 impairs neuronal patterns in the barrel cortex. Nature 406: 726-731. CrossRef Medline

Izhikevich EM, Desai NS, Walcott EC, Hoppensteadt FC (2003) Bursts as a unit of neural information: selective communication via resonance. Trends Neurosci 26:161-167. CrossRef Medline

Kim EH, Thu DC, Tippett LJ, Oorschot DE, Hogg VM, Roxburgh R, Synek BJ, Waldvogel HJ, Faull RL (2014) Cortical interneuron loss and symptom heterogeneity in Huntington disease. Ann Neurol 75:717-727. CrossRef Medline

Kirkwood PA (1979) On the use and interpretation of cross-correlations measurements in the mammalian central nervous system. J Neurosci Methods 1:107-132. CrossRef Medline

Kreitzer AC, Malenka RC (2008) Striatal plasticity and basal ganglia circuit function. Neuron 60:543-554. CrossRef Medline

Lee W, Reyes RC, Gottipati MK, Lewis K, Lesort M, Parpura V, Gray M (2013) Enhanced $\mathrm{Ca}(2+)$-dependent glutamate release from astrocytes of the BACHD Huntington's disease mouse model. Neurobiol Dis 58: 192-199. CrossRef Medline

Legéndy CR, Salcman M (1985) Bursts and recurrences of bursts in the spike trains of spontaneously active striate cortex neurons. J Neurophysiol 53: 926-939. Medline

Lewicki MS (1998) A review of methods for spike sorting: the detection and classification of neural action potentials. Network 9:R53-R78. CrossRef Medline

Li H, Wyman T, Yu ZX, Li SH, Li XJ (2003) Abnormal association of mutant huntingtin with synaptic vesicles inhibits glutamate release. Hum Mol Genet 12:2021-2030. CrossRef Medline

Liévens JC, Woodman B, Mahal A, Spasic-Boscovic O, Samuel D, Kerkerian-Le 
Goff L, Bates GP (2001) Impaired glutamate uptake in the R6 Huntington's disease transgenic mice. Neurobiol Dis 8:807-821. CrossRef Medline

Lisman JE (1997) Bursts as a unit of neural information: Making unreliable synapses reliable. Trends Neurosci 20:38-43. CrossRef Medline

McCormick DA, Connors BW, Lighthall JW, Prince DA (1985) Comparative electrophysiology of pyramidal and sparsely spiny stellate neurons of the neocortex. J Neurophysiol 54:782-806. Medline

Menalled L, El-Khodor BF, Patry M, Suárez-Fariñas M, Orenstein SJ, Zahasky B, Leahy C, Wheeler V, Yang XW, MacDonald M, Morton AJ, Bates G, Leeds J, Park L, Howland D, Signer E, Tobin A, Brunner D (2009) Systematic behavioral evaluation of Huntington's disease transgenic and knock-in mouse models. Neurobiol Dis 35:319-336. CrossRef Medline

Miller BR, Walker AG, Shah AS, Barton SJ, Rebec GV (2008) Dysregulated information processing by medium spiny neurons in striatum of freely behaving mouse models of Huntington's disease. J Neurophysiol 100: 2205-2216. CrossRef Medline

Miller BR, Walker AG, Barton SJ, Rebec GV (2011) Dysregulated neuronal activity patterns implicate corticostriatal circuit dysfunction in multiple rodent models of Huntington's disease. Front Syst Neurosci 5:26. CrossRef Medline

Miller BR, Dorner JL, Bunner KD, Gaither TW, Klein EL, Barton SJ, Rebec GV (2012) Upregulation of GLT1 reverses the deficit in cortically evoked striatal ascorbate efflux in the R6/2 mouse model of Huntington's disease. J Neurochem 121:629-638. CrossRef Medline

Milnerwood AJ, Gladding CM, Pouladi MA, Kaufman AM, Hines RM, Boyd JD, Ko RW, Vasuta OC, Graham RK, Hayden MR, Murphy TH, Raymond LA (2010) Early increase in extrasynaptic NMDA receptor signaling and expression contributes to phenotype onset in Huntington's disease mice. Neuron 65:178-190. CrossRef Medline

Nicniocaill B, Haraldsson B, Hansson O, O'Connor WT, Brundin P (2001) Altered striatal amino acid neurotransmitter release monitored using microdialysis in R6/1 Huntington transgenic mice. Eur J Neurosci 13:206210. CrossRef Medline

Orta-Salazar E, Feria-Velasco A, Medina-Aguirre GI, Díaz-Cintra S (2013) Morphological analysis of the hippocampal region associated with an innate behavior task in the transgenic mouse model (3xTg-AD) for Alzheimer disease. Neurologia 28:497-502. CrossRef Medline

Paxinos G, Franklin KBJ (2001) The mouse brain in stereotaxic coordinates, Ed 2. San Diego: Academic.

Rebec GV, Conroy SK, Barton SJ (2006) Hyperactive striatal neurons in symptomatic Huntington R6/2 mice: variations with behavioral state and repeated ascorbate treatment. Neuroscience 137:327-336. CrossRef Medline

Spampanato J, Gu X, Yang XW, Mody I (2008) Progressive synaptic pathology of motor cortical neurons in a BAC transgenic mouse model of Huntington's disease. Neuroscience 157:606-620. CrossRef Medline

Stanford JA, Gerhardt GA (2001) Age-related changes in striatal function of freely-moving F344 rats. Neurobiol Aging 22:659-669. CrossRef Medline
Szczypka MS, Kwok K, Brot MD, Marck BT, Matsumoto AM, Donahue BA, Palmiter RD (2001) Dopamine production in the caudate putamen restores feeding in dopamine-deficient mice. Neuron 30:819-828. CrossRef Medline

The Huntington's Disease Collaborative Research Group (1993) A novel gene containing a trinucleotide repeat that is expanded and unstable on Huntington's disease chromosomes. Cell 72:971-983. CrossRef Medline

Thomas EA, Coppola G, Tang B, Kuhn A, Kim S, Geschwind DH, Brown TB, Luthi-Carter R, Ehrlich ME (2011) In vivo cell-autonomous transcriptional abnormalities revealed in mice expressing mutant huntingtin in striatal but not cortical neurons. Hum Mol Genet 20:1049-1060. CrossRef Medline

Thu DC, Oorschot DE, Tippett LJ, Nana AL, Hogg VM, Synek BJ, LuthiCarter R, Waldvogel HJ, Faull RL (2010) Cell loss in the motor and cingulate cortex correlates with symptomatology in Huntington's disease. Brain 133:1094-1110. CrossRef Medline

Tong X, Ao Y, Faas GC, Nwaobi SE, Xu J, Haustein MD, Anderson MA, Mody I, Olsen ML, Sofroniew MV, Khakh BS (2014) Astrocyte Kir4.1 ion channel deficits contribute to neuronal dysfunction in Huntington's disease model mice. Nat Neurosci 17:694-703. CrossRef Medline

Traficante A, Riozzi B, Cannella M, Rampello L, Squitieri F, Battaglia G (2007) Reduced activity of cortico-striatal fibres in the R6/2 mouse model of Huntington's disease. Neuroreport 18:1997-2000. CrossRef Medline

Unschuld PG, Joel SE, Liu X, Shanahan M, Margolis RL, Biglan KM, Bassett SS, Schretlen DJ, Redgrave GW, van Zijl PC, Pekar JJ, Ross CA (2012) Impaired cortico-striatal functional connectivity in prodromal Huntington's disease. Neurosci Lett 514:204-209. CrossRef Medline

Vonsattel JP, DiFiglia M (1998) Huntington disease. J Neuropathol Exp Neurol 57:369-384. CrossRef Medline

Walker AG, Miller BR, Fritsch JN, Barton SJ, Rebec GV (2008) Altered information processing in the prefrontal cortex of Huntington's disease mouse models. J Neurosci 28:8973-8982. CrossRef Medline

Wang N, Gray M, Lu XH, Cantle JP, Holley SM, Greiner E, Gu X, Shirasaki D, Cepeda C, Li Y, Dong H, Levine MS, Yang XW (2014) Neuronal targets for reducing mutant huntingtin expression to ameliorate disease in a mouse model of Huntington's disease. Nat Med 20:536-541. CrossRef Medline

Wichmann T, Soares J (2006) Neuronal firing before and after burst discharges in the monkey basal ganglia is predictably patterned in the normal state and altered in parkinsonism. J Neurophysiol 95:2120-2133. Medline

Wilson CJ (1993) The generation of natural firing patterns in neostriatal neurons. Prog Brain Res 99:277-297. CrossRef Medline

Zuccato C, Ciammola A, Rigamonti D, Leavitt BR, Goffredo D, Conti L, MacDonald ME, Friedlander RM, Silani V, Hayden MR, Timmusk T, Sipione S, Cattaneo E (2001) Loss of huntingtin-mediated BDNF gene transcription in Huntington's disease. Science 293:493-498. CrossRef Medline 